Website: https://journal.stiba.ac.id

ISSN : 2685-7537 (online) 2338-5251 (Printed)

\title{
GOLONGAN YANG MENDAPATKAN RUKHSAH DALAM IBADAH PUASA DAN KONSEKUENSI HUKUMNYA
}

\author{
Irsyad Rafi
}

\author{
Sekolah Tinggi Ilmu Islam dan Bahasa Arab (STIBA) Makassar, \\ Jl. Inspeksi PAM Manggala-Antang Makassar \\ Email: irsyadrafi@stiba.ac.id
}

\begin{tabular}{|c|c|}
\hline Keywords : & ABSTRACT \\
\hline $\begin{array}{l}\text { category, rukhshah, fasting, } \\
\text { law consequence }\end{array}$ & $\begin{array}{l}\text { This study described the groups granted with Rukhsah (concession) } \\
\text { in Fasting and its Legal Consequence. The method used in this study } \\
\text { is library research. Various literature was collected to obtain data } \\
\text { and facts. These data are collected, sorted, selected and then analyzed } \\
\text { to answer the four primary studies that are what is the definition of } \\
\text { Rukhsah in general, what are the obstacles that allow Rukhsah to } \\
\text { be granted, what is the concept of Rukhsah in fasting? And which } \\
\text { categories are granted with the Rukhsah in fasting and what are the } \\
\text { legal consequences? The results of the study showed that the Rukhsab } \\
\text { is a law that applies based on an argument, which violates existing } \\
\text { legal arguments (the original law / azimah) due to udzur (obstacles). } \\
\text { The obstacles as the cause of Rukhshah includes: journey (safar), } \\
\text { sickness, necessity, forgetfulness, ignorance, conditions that are very } \\
\text { difficult to avoid, and insufficiency. Briefly udzur (obstacles) or the } \\
\text { requirements of Rukhsab could be: emergency (ad-darurah), or the } \\
\text { existence of difficulties (al-masyaqqah) or just needs (al-häjab). } \\
\text { Rukhșah is concession and the form of concession is concession } \\
\text { granted for not fasting in the month of Ramadhan with the } \\
\text { consequence of replacing the missed fasting in accordance with the } \\
\text { Shari'ah known as qada 'or fidyah. The Groups that are granted } \\
\text { with the Rukhshah in Fasting are sick, people, travelers, menstrual } \\
\text { and pureperal women, old people, pregnant or breastfeeding woman. } \\
\text { Those are udzur or the causes of a woman to be granted with } \\
\text { Rukhsah for not fasting. }\end{array}$ \\
\hline
\end{tabular}




\section{PENDAHULUAN}

Puasa ramadhan adalah ibadah yang agung, titah perintah dari Sang Maha Esa yang tertuang dalam QS. alBaqarah/2: 183.

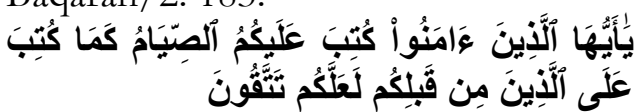

Terjamahnya:

"Hai orang-orang yang beriman, diwajibkan atas kamu berpuasa sebagaimana diwajibkan atas orang-orang sebelum kamu agar kamu bertakwa"

Kedudukan puasa ramadhan dalam Islam dan bagi kaum muslimin sangatlah penting. Ia adalah sebuah kewajiban yang harus ditunaikan sebagaimana kewajiban shalat lima waktu. Karena itu, setiap muslim seyogyanya memahami hal-hal yang berkenaan dengannya. Agar tercapai tujuan ibadah yakni diterima disisi Allah swt. yang dimana salah satu syaratnya adalah harus sesuai dengan petunjuk-Nya.

Sebagian kaum muslimin terlalu longgar dalam menjalankan syariat puasa, sampai pada tahap meninggalkan puasa tanpa menggantinya dengan dalih bahwa syariat tidak memberatkan ummatnya. Sebagian lagi terlalu bersemangat dalam menjalankan ibadah ini hingga terkesan mempersulit diri, padahal ada keringanan yang disiapkan. Keduanya merupakan realita yang terjadi ditengah kaum muslimin, karena kurangnya pemahaman terhadap konsep rukhșah dalam ibadah puasa.

1. Apa pengertian rukhșah secara umum?

2. Bagaimana ketentuan udzur yang dianggap sebagai sebab rukhșah?

${ }^{1}$ Kementrian Agama, Al-Qur'an dan Terjemahya (Depok; Sabiq 2012), h.28.
3. Bagaimana konsep rukhșah dalam ibadah puasa?

4. Siapa saja yang mendapatkan rukhșah dalam ibadah puasa dan apa saja konsekuensi hukumnya?

\section{PEMBAHASAN}

\section{A. Tinjauan Umum tentang Rukhṣah}

Secara bahasa, kata rukbșah (رخصة) berasal dari kata rakhuṣa (رخُص) yang secara umum bermakna "keringanan dan kemudahan", juga memiliki makna lain sebagaimana yang disebutkan dalam Lisān al- Arab $^{(2)}$, kata rukhșah mempunyai banyak makna, diantaranya adalah:

1. Halusnya sentuhan. Dikatakan "rakhuṣa al badanu" (badan yang halus dan lembut sentuhannya).

2. Turunnya harga. (رخص الشئ رخصا) " rakbușa asy syai'u rukbșan" (harga barang itu murah).

3. Izin terhadap sesuatu setelah ada larangan. (رخص له في الأمر) rakbuṣa labu fil amri" (dizinkan suatu perkara untuknya).

Kata rukbșah mengikuti wazan fullah, seperti lafadz gurfah, yang menjadi lawan kata dari tasydid (memberatkan), yakni rukbșah dimaknai sebagai pemberian kemudahan dalam sesuatu. Dikatakan, "Rakbkhaṣa asy-Syar'u fi każä tarkbișah" (syariat memberi kemudahan dalam masalah ini). ${ }^{3}$ Rasulullah saw. bersabda:

2Ibnu al-Manz̦ūr, Lisan al-'Arab, Juz VII (Cet.3, Beirut, Dār Ṡādir, 1994), h. 40-41.

${ }^{3}$ Kementrian Agama Kuwait, alMawsū'ah al-Fiqhiyyah Juz XXII (Cet.1, Kuwait, Dār as-Ṡafwah, 1995) h.151. 


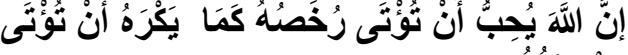

Artinya:

"Sesungguhnya Allah senang jika didatangi rukhșah

(kemudahan) yang Ia berikan, sebagaimana Dia benci ketika didatangi maksiatNya"

Para ulama Ushul Fiqh

berbeda ketika mendefinisikan rukbșah dengan beberapa definisi. Prof. Dr. Abdul Karim an-Namlah dalam bukunya ${ }^{(5)}$, setidaknya menyebutkan empat belas definisi yang diungkapkan oleh ulama ushul.

Diantaranya adalah al-Āmidī, beliau mendefinisikan rukhșah dengan sesuatu yang disyariatkan karena udzur, tetapi dalil pengharaman tetap berlaku. Adapun asy-Syāțibī berpendapat bahwa rukhsah adalah sesuatu yang disyariatkan karena udzur yang sulit, sebagai pengecualian dari hukum asli yang umum sebelumnya dilarang, dengan ketentuan hanya dimanfaatkan pada saat-saat yang dibutuhkan. Sementara Imam alGhazali mendefinisikan rukhșah sebagai sesuatu yang boleh dilakukan padahal hukumnya haram.

Dr. al-Namlah kemudian memilih pendapat al-Bayḍ̄āwi dalam mendefinisikan rukhșah setelah memberikan komentar dan sanggahan pada setiap defenisi para ulama ushul.

Secara umum rukhșah diartikan dengan:

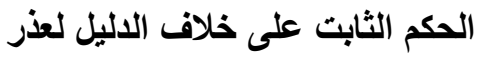

Artiya:

${ }^{4}$ Ahmad Ibn Hanbal, Musnad Al-Imām Ahmad Ibn Hanbal Juz X, (cet, II; t.p, Muassasah Al-Risālah, 1999), h.107.

${ }^{5}$ Abdul Karim Al-Namlah, Al-Rukhaș AlSyar'iyyah wa Iśbātuhā bi Al-Qiyās, (Cet.1, Riyadh, Maktabah ar-Rusyd, 1990) h. 12-44.
"Hukum yang berlaku berdasarkan suatu dalil, yang menyalahi dalil hukum yang sudah ada karena adanya udzur"

Defenisi ini dipilih karena telah mencakup defenisi-defenisi lainnya yang diungkapkan para ulama ushul yang kesemuanya bersepakat pada tiga poin :

1. Adanya dalil yang menjadi pondasi dari berlakunya rukhșah.

2. Adanya udzur yang membolehkan keluar dari hukum asli(azimab) menuju rukhșah.

3. Hukum rukhșah bukanlah merupakan hukum terapan yang asli, melainkan ia hanya merupakan hukum yang ditetapkan Allah Subhānabüwrata'àlā untuk meringankan mukallaf/manusia dan mengangkat kesulitan yang dihadapi.

Rukbșah adalah lawan dari 'azimah, hal ini dikarenakan azimah adalah perintah untuk mengamalkan sesuatu sesuai dengan dalil yang ada. Sementara rukhșah adalah mengamalkan sesuatu yang tidak sesuai dengan dalil yang ada, dikarenakan adanya udzur yang menjadi halangan pelaksanaannya.

Dari sini dapat disimpulkan bahwa hukum rukhșah adalah:

1. Hukum yang disyariatkan pada tahap kedua, sebagai bentuk pengecualian dari hukum asli yang umum yaitu 'azimah.

2. Bahwa dalil hukum asli yaitu 'arimah masih tetap berlaku dan masih harus dilaksanakan bagi orang yang tidak memiliki udzur.

3. Faktor udzur lah yang menjadi sebab dilaksanakannya rukhșah.

Dari sini dapat disimpulkan bahwa adanya rukhșah adalah sebagai bentuk kemurahan dari Allah Subhānahüwata'àlā kepada para 
hambaNya, terutama ketika kondisi tidak memungkinkan untuk melaksanakan 'azimah tersebut.

\section{B. Ketentuan udzur yang dianggap sebagai sebab rukhṣah.}

Sudah diketahui melalui defenisi rukhsah yang telah disebutkan, bahwa faktor udzur lah yang menjadi sebab seseorang mengambil rukhșah. Sebelum menuju ke pembahasan lebih lanjut, terlebih dahulu kita harus mengetahui udzur mana saja yang dimaksudkan. Para ulama telah menyebutkan udzur atau sebab rukbșah diantaranya al-Suyuthi yang menyebutkan tujuh sebab rukhșah sebagai berikut ${ }^{6}$

1. Safar (السفر).

2. Sakit (المرض).

3. Paksaan (الإكراه).

4. Lupa (النسيان).

5. Kebodohan (الجهل).

6. Keadaan yang sangat sulit dihindari (العسر وعموم البلوى).

7. Kekurangan (النقص)

Secara singkat udzur atau sebab seseorang mengambil rukbșah itu bisa berupa adanya keterpaksaan (ad-darürab), atau adanya kesulitan (almasyaqqah) ataupun sekedar kebutuhan (al-bajjah). Akan tetapi hal ini tidak memiliki ukuran yang pasti antara setiap orang dengan yang lainnya. Kapan ia harus bertahan dengan 'azimah (hukum asal), dan kapan ia sudah bisa mengambil rukhșah/keringanan.

Sebagai contoh: Masalah udzur sakit, sebagian orang ada yang kuat dengan penyakit yang ia derita,

${ }^{6} \mathrm{Al}-\mathrm{Suyūțī,} \quad$ Al-Asybāh wa Al-Naẓāir, (Cet.1, Beirut; Dar al-Kutub al-'Ilmiyah, 1983), h. $77-80$ adapula yang tidak kuat walaupun dari segi medis kadar penyakitnya sama. Tapi rukbșah disini diperuntukkan hanya kepada orang yang tidak kuat saja.

Contoh lain: Seorang yang terbiasa bersabar dengan rasa lapar dan tidak mempengaruhi keadaannya, ia tidak diberi rukhsah untuk makan bangkai. Beda halnya dengan seseorang yang tidak terbiasa dengan rasa lapar, ia dibolehkan makan bangkai. Karena kalau tidak, dikhawatirkan akan mendatangkan mudharat pada dirinya.

Maka sekali lagi udzur tidak memiliki ukuran yang paten, dan kesulitan hendaknya dikembalikan kepada setiap person. Tergantung dengan ijtihad masing-masing yang bersandarkan pada kekuatannya dalam menghadapi kesulitan tersebut, keimanan serta sifat wara'nya.

Akan tetapi satu hal yang perlu diperhatikan bahwa dalam mengambil rukhșah, hendaklah setiap orang berhati-hati sebisa mungkin. Artinya ia tidak mengambil rukhșah tersebut kecuali ia telah benar-benar yakin bahwa ia sangat membutuhkan rukhșah tersebut. Karena ada sebagian orang "tatabbu' rukbaș" hanya sekedar mencari kemudahan dan lari dari perintah dan larangan syariat, maka hal ini merupakan suatu yang dilarang. ${ }^{7}$

\section{Rukhsah Dalam Ibadah Puasa}

Ditinjau dari segi hukum, puasa terbagi menjadi dua yakni: puasa wajib dan puasa sunnah. Akan tetapi pembahasan pokok dalam rangkaian tulisan ini adalah mengenai puasa wajib di bulan ramadhan.

Setiap muslim seyogyanya memahami bahwa Ibadah puasa tidak

${ }^{7}$ Abdul Karim Al-Namlah, Al-Rukhaș AlSyar'iyyah wa lśbātuhā bi Al-Qiyās, h. 12-44. 
bersifat memberatkan, sehingga setiap muslim harus mengetahui kemudahankemudahan yang telah ditetapkan oleh Allah swt. kepada para hamba-Nya pada keadaan-keadaan tertentu dalam berpuasa. Hal tersebut biasa diistilahkan dengan rukhșah. Tetapi dengan adanya rukhșah, bukan berarti menjadi alasan untuk meninggalkan kewajiban berpuasa di bulan ramadhan.

Sebagaimana yang telah dijelaskan bahwa rukbșah adalah keringanan. Maka bentuk keringanan yang dimaksud dalam ibadah puasa ini adalah, keringanan untuk tidak berpuasa pada waktu yang telah ditentukan yakni bulan ramadhan. Tentu dengan konsekuensi mengganti puasa yang ditinggalkan sesuai dengan ketentuan yang telah digariskan oleh syari'at.

Secara garis besar, pengganti puasa ramadhan ada dua bentuknya:

Pertama: Menggantinya dengan berpuasa yang semisal, sejumlah hari yang ditinggalkan dalam bulan ramadhan, yang biasa diistilahkan dengan qaḍa. Puasa qad̄a dikerjakan kapan pun diluar bulan ramadhan dengan syarat, yakni dikerjakan sebelum datangnya ramadhan berikutnya.

Kedua: Membayar fidyah, bagi orang yang sama sekali tidak mampu untuk membayar utang puasanya dengan cara mengqadia.

D. Golongan yang Mendapatkan Rukhṣah dalam Ibadah Puasa.

Berikut golongan orang-orang yang mendapatkan rukhșah dalam puasa, yakni keringanan berbuka/tidak berpuasa di siang bulan ramadhan.
Yang akan kami paparkan sesuai dengan jenis udzurnya. ${ }^{8}$

\section{a. Orang Sakit.}

Yang dimaksudkan sakit adalah seseorang yang mengidap penyakit yang membuatnya tidak lagi dikatakan sehat. Para ulama telah sepakat mengenai bolehnya orang sakit untuk tidak berpuasa secara umum. Nanti ketika sembuh, dia diharuskan mengqad $\vec{a}$ ' puasanya yakni menggantinya kapan pun diluar bulan ramadhan sebelum datangnya ramadhan berikutnya. Dalil mengenai hal ini adalah firman Allah swt. QS. QS. al-Baqarah/2: 185.

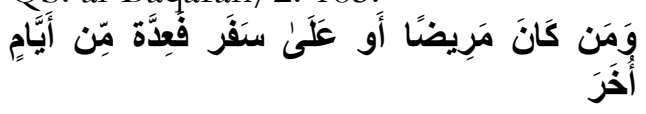

Terjemahnya:

Dan barang siapa sakit atau dalam perjalanan (lalu ia berbuka), maka (wajiblah baginya berpuasa), sebanyak hari yang ditinggalkannya itu, pada hari-hari yang lain. ${ }^{’}$ kondisi :

Untuk orang sakit ada tiga

Kondisi pertama adalah apabila sakitnya ringan dan tidak berpengaruh apa-apa jika tetap berpuasa. Contohnya adalah pilek, pusing atau sakit kepala yang ringan, dan perut keroncongan. Untuk kondisi pertama ini tetap diharuskan untuk berpuasa dan tidak termasuk golongan yang mendapat rukhșah.

Kondisi kedua adalah apabila sakitnya bisa bertambah parah atau akan menjadi lama sembuhnya dan menjadi berat jika berpuasa, namun tidak sampai membahayakannya. Untuk kondisi ini dianjurkan untuk

${ }^{8}$ Kamal bin Sayyid Salim, Șaḥịn Fiqh Sunnah, Juz II (Cet.1, Cairo; al-Maktabah alTawfīqīyyah), h. 118-127.

9 Kementrian Agama, Al-Qur'an dan Terjemahya, h.83. 
tidak berpuasa dan dimakruhkan jika tetap ingin berpuasa.

Kondisi ketiga adalah apabila tetap berpuasa akan menyusahkan dirinya, bahkan bisa mengantarkan pada kematian. Untuk kondisi ini diharamkan untuknya berpuasa. Hal ini berdasarkan firman Allah swt. QS. al-Nisā'/4: 29.

\section{وَلا تَقَتُُْوا أَنْفُسَكُمْ}

Terjemahnya

"Dan janganlah kamu membunuh dirimu." 10

Masalah: Apakah orang yang dalam kondisi sehat boleh tidak berpuasa karena jika berpuasa dia ditakutkan sakit?

Boleh untuk tidak berpuasa bagi orang yang dalam kondisi sehat yang ditakutkan akan menderita sakit jika dia berpuasa. Karena orang ini dianggap seperti orang sakit yang jika berpuasa sakitnya akan bertambah parah atau akan bertambah lama sembuhnya. Allah swt. Berfirman:

1. QS. al-Nisā'/4: 29.

\section{وَلا تَقَتُشُوا أَنْفُسَكُمْ}

Terjemahnya:

"Dan janganlah kamu membunuh dirimu."

2. QS. al-Baqarah/2: 185.

Terjemahnya:

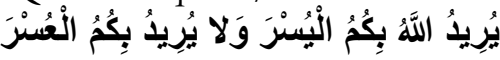

"Allah menghendaki kemudahan bagimu, dan tidak menghendaki kesukaran bagimu"11

3. QS. al-Hāijj/22:78.

Terjemahnya:

\section{وَمَا جَعَلَ عَلَيْعُمْ فِي الآَّينِ مِنْ حَرَج}

"Dia telah memilih kamu dan

Dia sekali-kali tidak menjadikan

10 Kementrian Agama, Al-Qur'an dan Terjemahya, h.83.

11 Kementrian Agama, Al-Qur'an dan Terjemahya, h.28. untuk kamu dalam agama suatu kesempitan"12

4. Sebuah hadis yang diriwayatkan oleh imam Bukharī dan Muslim.

Artinya:

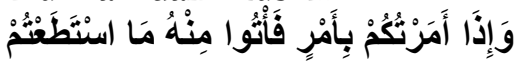

"Jika aku memerintahkan kalian untuk melakukan suatu perkara, maka lakukanlah semampu kalian."(13)

\section{b. Musafir (orang yang bepergian} jauh).

Musafir yang melakukan perjalanan jauh sehingga mendapatkan keringanan untuk mengqașar shalat ${ }^{14}$ dibolehkan untuk tidak berpuasa. Dan dia diharuskan meng-qad $\vec{a}$ ' puasanya yakni menggantinya kapan pun diluar bulan ramadhan sebelum datangnya ramadhan berikutnya. Dalilnya adalah firman Allah swt. QS. al-Baqarah/2 185.

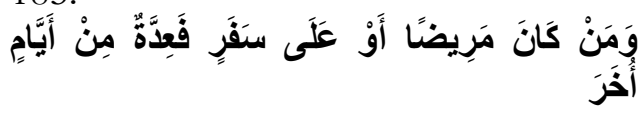

Terjemahnya:

Dan barang siapa sakit atau dalam perjalanan (lalu ia berbuka), maka (wajiblah baginya berpuasa), sebanyak hari

12 Kementrian Agama, Al-Qur'an dan Terjemahya, h.341.

${ }^{13}$ Muḥammad ibn Ismāīl ibn Ibrāhīm ibn Al-Mugīrah Al-Bukharī, Șaḥị̣ Al-Bukharī, Juz IX, (t.p; Dār Ṭauq Al-Najāh, 1422H), h. 94.

${ }^{14}$ Para ulama berselisih pendapat mengenai batasan jarak hingga disebut safar sehingga boleh mengqașar shalat. Pertama : jarak perjalanan sehari semalam atau 4 burud = 16 farsakh = 86 km. Kedua: jarak perjalanan tiga hari tiga malam. Ketiga : tidak adanya batasan jarak safar, selama sudah disebut safar(secara 'urf), maka sudah boleh mengqașar shalat. 
yang ditinggalkannya itu, pada hari-hari yang lain. ${ }^{15}$

Masalah: Manakah yang lebih utama bagi orang yang bersafar, berpuasa atau berbuka?

Para ulama dalam hal ini berselisih pendapat. Setelah meneliti lebih jauh dan menggabungkan berbagai macam dalil, dapat kita katakan bahwa musafir memiliki tiga kondisi.

Kondisi pertama adalah jika berat untuk berpuasa atau sulit melakukan hal-hal yang baik ketika itu, maka lebih utama untuk tidak berpuasa. Dalil dari hal ini dapat kita lihat dalam hadits Jabir bin Abdillah ra. Beliau mengatakan:

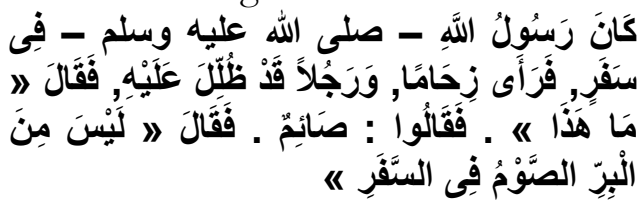

Artinya:

Rasulullah shallallahu 'alaihi wa sallam ketika bersafar melihat orang yang berdesak-desakan. Lalu ada seseorang yang diberi naungan. Lalu Nabi shallallahu 'alaihi wa sallam mengatakan, "Siapa ini? "Orang-orang pun mengatakan, "Ini adalah orang yang sedang berpuasa." Kemudian Nabi saw bersabda, "Bukanlah suatu yang baik jika seseorang berpuasa ketika dia bersafar". ${ }^{16}$

Di sini dikatakan tidak baik berpuasa ketika safar karena ketika itu adalah kondisi yang menyulitkan.

Kondisi kedua adalah jika tidak memberatkan untuk berpuasa dan tidak menyulitkan dalam

15 Kementrian Agama, Al-Qur'an dan Terjemahya, h.28.

${ }^{16}$ Muhammad ibn Ismāīl ibn Ibrāhīm ibn Al-Mugīrah Al-Bukharī, Șaḥị̣ Al-Bukharī, Juz IX, h. 34 . melakukan berbagai kebaikan, maka pada kondisi seperti ini lebih utama untuk berpuasa. Hal ini sebagaimana dicontohkan oleh Nabi shallallahu 'alaihi wa sallam, di mana beliau masih tetap berpuasa ketika safar.

$$
\text { Dari Abū Darda ra, beliau }
$$

berkata:

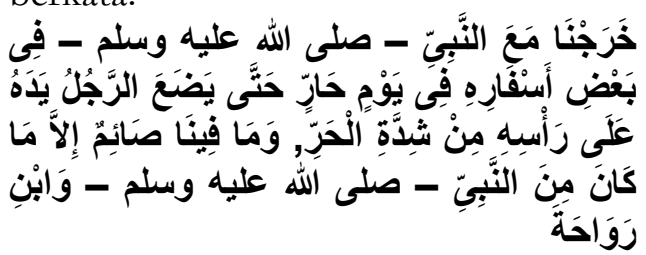

Artinya:

Kami pernah keluar bersama Nabi shallallahu 'alaihi wa sallam di beberapa safarnya pada hari yang cukup terik. Sehingga ketika itu orang-orang meletakkan tangannya di kepalanya karena cuaca yang begitu panas. Di antara kami tidak ada yang berpuasa. Hanya Nabi shallallahu 'alaihi wa sallam saja dan Ibnu Rowahah yang berpuasa ketika itu. ${ }^{17}$

Apabila tidak terlalu menyulitkan ketika safar, maka puasa itu lebih baik karena lebih cepat terlepasnya kewajiban. Begitu pula puasa lebih mudah dilakukan karena berpuasa dengan orang banyak itu lebih menyenangkan daripada mengqad $\vec{a}$ puasa sendiri sedangkan orangorang sedang tidak berpuasa.

Kondisi ketiga adalah jika berpuasa akan mendapati kesulitan yang berat bahkan dapat mengantarkan pada kematian, maka kondisi seperti ini wajib tidak berpuasa dan diharamkan untuk berpuasa. Dari Jabir bin Abdillah ra, beliau berkata:

${ }^{17}$ Muslim Ibn Al-Hajjāj Al- Qusyairī AlNaisāburī, Șaḥịh Muslim, Juz II (Bairūt; Dār AlKutub Al-Arābiyah, 2010), h. 790. 


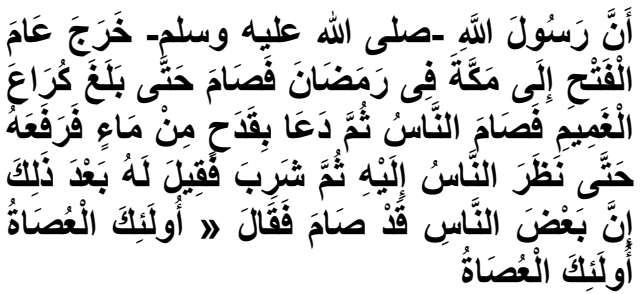

Artinya:

Sesungguhnya Rasulullah shallallahu 'alaihi wa sallam keluar pada tahun (Fathu Makkah) menuju Makkah di bulan Ramadhan. Beliau ketika itu berpuasa, hingga ketika sampai di Kurā' al-Gamīm (suatu lembah antara Mekkah dan Madinah), orang-orang ketika itu masih berpuasa. Kemudian beliau meminta diambilkan segelas air. Lalu beliau mengangkatnya dan orang-orang pun memperhatikan beliau meminum air tersebut. Setelah beliau melakukannya, ada yang mengatakan: "Sesungguhnya sebagian orang ada yang tetap berpuasa." Rasulullah shallallahu 'alaihi wa sallam pun mengatakan, "Mereka itu adalah orang yang durhaka. Mereka itu adalah orang yang durhaka. ${ }^{18}$

Nabi saw. mencela orangorang tersebut karena mereka berpuasa dalam kondisi sangat sulit seperti ini.

Masalah: Apakah hukum musafir berlaku bagi para sopir mobil, bus, atau truk? Karena pekerjaan mereka yang terus-menerus di siang hari pada bulan Ramadhan. Bahkan para sopir luar kota mungkin lebih bekerja giat di bulan ramadhan, terlebih di musim

${ }^{18}$ Muhammad Ibn Ishāq Ibn Khuzaimah, Sahīh Ibn Khuzaimah, Juz III (Bairūt; Al-Maktab Al-Islamiyah, 1970), h. 255. mudik. Apakah mereka boleh tidak berpuasa?

Ulama menjelaskan bahwa sopir jika ke luar kota dan perjalanannya dikatagorikan termasuk safar, maka mereka mendapatkan semua rukhșah (keringanan) safar seperti menqasar dan menjamak shalat, dan mengusap khuff selama tiga hari. Begitupula ia mendapatkan rukhșah tidak berpuasa pada bulan ramadhan dan mengqadänya di hari yang lain. Dan tentunya juga berlaku hukum lebih utama mana baginya berbuka atau berpuasa, sebagaimana yang telah dijelaskan. Hal ini sebagaimana yang difatwakan oleh Syaikh al-'Uśaimin'19, Syaikh bin $\mathrm{Baz}^{20}$ dan juga merupakan fatwa resmi dari lembaga komisi fatwa Saudi Arabiyah, al-Lajnah adDāimah. $^{21}$

\section{c. Wanita Haid dan Nifas}

Para ulama sepakat bahwa wanita yang tengah menjalani masa haid dan nifas tidak boleh berpuasa. Keduanya dibolehkan berbuka, tetapi harus menggantinya pada hari-hari yang lain. Dan jika keduanya tetap berpuasa, maka puasanya tidak sah. Sebagaimana sebuah riwayat dari Aisyah radiyallabu 'anba beliau mengatakan :

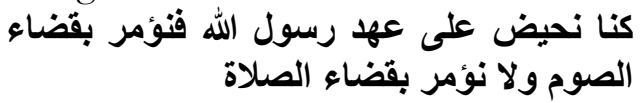

Artinya:

"Kami haidh di zaman Rasulullah, maka kami

${ }^{19}$ Faḥd al-Sulaiman, Majmū' Fatāwā wa rasāil Syaikh al-'Uśaimīn, Juz XIX (Riyadh; Dar alŚurayyā, 2003), h. 141-142.

${ }^{20}$ Abdullah Bin Baz, Fatwa Nūrun 'alā AlDarb, Juz.XVI, (Cet.1, Riyadh; ar-Riāsah al'Āmmah lil Buhūis al-'Ilmiyyah wal Iftā, 2010), h. 145-147.

${ }^{21}$ Ahmad ad-Duwaysy, Fatāwā al-Lajnah ad-Dāimah, Juz.X (cet 1, Riyāḍ; Dar al-'Āṣimah, 1996), h. 204. 
diperintahkan untuk mengganti puasa dan tidak diperintahkan untuk mengganti shalat" ${ }^{, 22}$

\section{d. Orang Tua Renta dalam Keadaan Lemah, dan Orang Sakit yang Tidak Diharapkan Kesembuhannya}

Para ulama sepakat bahwa orang tua yang tidak mampu berpuasa, boleh baginya untuk tidak berpuasa dan tidak ada qad $\vec{a}$ ' baginya, walaupun mereka berbeda pendapat mengenai keharusan membayar fidyah jika tidak berpuasa. Menurut mayoritas ulama, wajib bagi mereka fidyah yaitu memberi makan satu orang miskin setiap hari yang ditinggalkan. Adapun Imam Malik, beliau berpendapat bahwa fidyah hukumnya mustahab, tidak harus. Pendapat mayoritas ulama lebih kuat karena berdasarkan dalil-dalil. Diantaranya firman Allah swt. QS. al Baqarah/2: 184.

Terjemahnya:

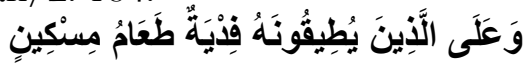

"Dan wajib bagi orang-orang yang berat menjalankannya (jika mereka tidak berpuasa) membayar fidyah, (yaitu): memberi makan seorang miskin"23

Ibnu Abbas berkata mengomentari ayat ini bahwa yang dimaksudkan adalah orang tua yang tidak mampu berpuasa, maka hendaknya memberi makan satu orang miskin setiap hari yang ditinggalkan.

Begitu pula orang sakit yang tidak kunjung sembuh dan tidak ada harapan untuk sembuh, dia disamakan dengan orang tua renta yang tidak mampu melakukan puasa sehingga dia diharuskan membayar fidyah.

${ }^{22}$ Muslim Ibn Al-Hajjāj Al- Qusyairī AlNaisāburī, Șaḥị̣ Muslim, Juz I, h. 265.

23 Kementrian Agama, Al-Qur'an dan Terjemahya, h.28.

\section{e. Wanita Hamil dan Menyusui}

Hamil ataupun menyusui adalah dua kondisi yang sebenarnya bukan merupakan udzur atau sebab wanita mendapatkan rukhșah untuk tidak berpuasa. Kesimpulan ini kami peroleh dari apa yang disebutkan oleh al-Jașșāṣ dalam bukunya Aḥkām alQur'an $^{24}$ dan salah satu fatwa syaikh al-'Utsaimin ra ${ }^{25}$ bahwa wanita hamil dan menyusui tidak lepas dari dua kondisi :

Kondisi pertama: Kondisi wanita hamil dan menyusui sehat, kuat, tidak ditimpa kesulitan, dan tidak berdampak buruk bagi anaknya. Maka wanita seperti ini wajib baginya berpuasa, karena tidak ada udzur baginya untuk meninggalkan puasa.

Kondisi seperti ini bisa ditinjau dari dua hal:

- Wanita dengan kondisi fisik yang prima dan kuat.

1. Ibu hamil yang tidak mengalami sering muntah atau morning sickness (muntah di pagi hari) pada trimester pertama ${ }^{(26)}$.

2. Semua ibu hamil yang sehat (tidak memiliki penyakit) setelah fase trimester pertama.

3. Ibu menyusui setelah masa pemberian ASI eksklusif (6 bulan pertama).

- Wanita hamil dan menyusui yang sehat karena asupan nutrisi dan cairan yang tercukupi selama puasa.

${ }^{24} \mathrm{Al}$-Jașșāṣ, Aḥkām al-Qurān, Juz I (Beirut, Dar Ihyā' al-Turāṡ al-'Arabī, 1992), h. 223.

${ }^{25}$ Faḥd al-Sulaiman, Majmū' Fatāwā wa rasāil Syaikh al-'Uśaimìn, h. 161-162.

26 Trimester kehamilan adalah pembagian usia kehamilan menjadi tiga fase. Trimester pertama adalah fase pertama pada usia kehamilan 0-12 pekan atau 3 bulan pertama usia kehamilan. 
Semua wanita hamil (selain ibu hamil pada trimester pertama yang mengalami muntah) dan menyusui (selain ibu menyusui ASI eksklusif) bisa berpuasa dengan memenuhi asuapan nutrisi dan cairan selama berpuasa agar tidak bermudharat (seperti mengalami dehidrasi atau menurunnya kualitas ASI yang berakibat pada kesehatan bayi). Bisa disiasati pada saat berbuka dan sahur, serta menghindari mengkonsumsi makanan atau minuman yang cepat menurunkan vitalitas tubuh saat berpuasa (atau dengan berkonsultasi dengan ahli).

Kondisi kedua: Kondisi fisik wanita hamil dan menyusui yang tidak prima atau tidak memungkinkan untuk berpuasa, seperti:

1. Ibu hamil yang mengalami muntah pada trimester pertama.

2. Ibu hamil dan menyusui, yang jika ia berpuasa maka akan mengakibatkan mudharat pada diri dan atau anaknya atas diagnosa ahli/dokter.

3. Ibu menyusui ASI eksklusif (6 bulan pertama), yang jika ia berpuasa maka kualitas ASInya menurun yang berakibat buruk pada kesehatan anaknya.

Kondisi seperti ini, walaupun sudah di siasati pola nutrisinya tetap memberikan mudharat jika ia tetap berpuasa. Maka pada kondisi ini ia hendaknya berbuka.

Kondisi kedua ini yakni wanita hamil atau menyusui mendapatkan rukhșah untuk tidak berpuasa terbagi menjadi tiga keadaan, berikut penjelasannya disertai rincian konsekuensi hukumnya:

\section{Untuk wanita hamil dan menyusui yang mengkhawatirkan keadaan dirinya saja bila berpuasa}

Tidak ada perselisihan bahwa ia tidak wajib berpuasa dan wajib mengqodho puasanya, diqiyaskan terhadap orang yang sakit. Sebagaimana yang dinukilkan oleh Ibnu Qudamah $\mathrm{ra}^{27}$ dan Imam Nawawi ra. ${ }^{28}$

2. Untuk wanita hamil dan menyusui yang mengkhawatirkan keadaan dirinya dan buah hati

Kondisi ini sama seperti kondisi yang pertama.

\section{Untuk wanita hamil dan menyusui yang mengkhawatirkan keadaan si buah hati saja}

Kondisi seperti ini, sebenarnya sang wanita mampu untuk berpuasa. Akan tetapi akan berdampak buruk kepada anaknya jika ia tetap berpuasa walaupun telah memenuhi asupan nutrisi dan cairannya pada saat sahur dan berbuka. Hal ini tentu berdasarkan pengalaman atau diagnosa dokter.

Untuk kondisi ketiga ini, juga dibolehkan tidak berpuasa. Tetapi para ulama berbeda pendapat tentang konsekuensi hukum puasa yang ditinggalkannya. Berikut sedikit paparan tentang perbedaan pendapat tersebut ${ }^{(29)}$ :

a. Pertama, mewajibkan wanita hamil dan menyusui untuk mengqadä'saja

Dalil yang digunakan adalah sama sebagaimana kondisi pertama

\footnotetext{
${ }^{27}$ Ibnu Qudamah Al-Maqdisī, Al-Mugnī,
} Juz IV (Cet.3, Riyadh; Dār 'Ālam al-Kutub, 1997), h. 394.

${ }^{28} \mathrm{Al}$-Nawawī, Al-Majmū' Syarh alMuhażżab Juz VI (Cet.1, Beirut; Dar al-Turaś al'Arabī, 2001) h. 177.

${ }^{29}$ Kamal bin Sayyid Salim, Șahịh Fiqh

Sunnah, (Cet.1, Cairo, al-Maktabah alTawfīqīyyah), Vol.2, h. 125-127. 
dan kedua, yakni sang wanita hamil atau menyusui ini disamakan statusnya atau diqiyaskan sebagaimana orang sakit. Pendapat ini dipilih oleh Imam Abu Hanifah rabimahullah.

b. Kedua, mewajibkan wanita hamil dan menyusui untuk membayar fidyah saja

Di antara dalil mereka yaitu :

1. Sebuah riwayat dari Ibnu 'Abbās ra bahwa beliau berkata:

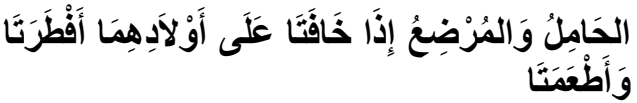

Artinya:

Wanita hamil atau menyusui dalam keadaan keduanya takut terhadap anaknya boleh bagi keduanya berbuka (tidak berpuasa) dan wajib bagi keduanya membayar fidyah. ${ }^{30}$

2. Juga riwayat Ibnu Abbas radbiallabu'anbuma, beliau berkata kepada seorang wanita hamil dan menyusui :

Engkau posisinya seperti orang tua renta yang tidak mampu (berpuasa). Wajib atasmu memberi makan satu orang miskin untuk setiap hari (yang engkau tidak berpuasa) seperdua șā hințah. ${ }^{31}$

3. Sebuah riwayat dari Nafi' Mawlā Ibnu 'Umar ra, beliau berkata:

Ibnu umar memiliki putri yang dipersunting oleh seorang Quraysy, ia sedang hamil dan suatu ketika ia merasa kehausan yang sangat dibulan ramadhan, maka ia pun diperintahkan oleh Ibnu 'Umar untuk berbuka dan

${ }^{30} \mathrm{HR}$. Abu Dawud no. 2318. Dishahihkan oleh Syaikh al-Albani rahimahullah dalam AlIrwa` no. 912

${ }^{31} \mathrm{HR}$. Abdurrazzaq no. 7567 , dan adDaraqutni (2/206). memberi makan seroang miskin untuk setiap harinya. ${ }^{32}$

Dan ayat QS. al-Baqarah/2: 184 yang dijadikan dalil bahwa wanita hamil dan menyusui hanya membayar fidyah adalah :

"Dan wajib bagi orang yang berat menjalankannya (jika mereka tidak berpuasa) membayar fidyah (yaitu) memberi makan satu orang miskin." 33

Hal ini disebabkan wanita hamil dan menyusui yang mengkhawatirkan anaknya dianggap sebagai orang yang tercakup dalam ayat ini.

Pendapat ini adalah pendapat yang dikuatkan oleh Syaikh al-Albani $\mathrm{ra}^{34}$ Juga pendapat ini dipilih oleh penulis buku Șahị Fịh as-Sunnah. ${ }^{35}$

c. Ketiga, mewajibkan wanita hamil dan menyusui untuk mengqada $\bar{a}$ disertai membayar fidyah.

Dalil kewajiban wanita mengqa $d \vec{a}$ ' adalah sebagaimana dalil pada kondisi pertama dan kedua, yaitu wajibnya bagi orang yang tidak berpuasa untuk mengqad $\vec{a}$ ' dihari lain ketika telah memiliki kemampuan. Para ulama berpendapat tetap wajib mengqad $\vec{a}$ ' puasa ini karena tidak ada dalam syari'at yang menggugurkan qạd $\bar{a}$ ' bagi orang yang mampu mengerjakannya.

${ }^{32}$ Muhammad Nashiruddin Al-Albani, Irwō' al-Galīl, Juz IV (Cet.1, Beirut; al-Maktab alIslami, 1979), h. 18.

${ }^{33}$ Kementrian Agama, Al-Qur'an dan Terjemahya, h.28.

${ }^{34}$ Muhammad Nashiruddin Al-Albani, Irwā' al-Galīl, Juz IV, h. 17-25.

${ }^{35}$ Kamal bin Sayyid Salim, Șahịh Fiqh Sunnah, Juz II (Cet.1, Cairo; al-Maktabah alTawfíqīyyah), h. 127. 
Sedangkan dalil wajibnya fidyah adalah sebagaimana dalil pendapat kedua.

Adapun perkataan Ibnu Abbas dan Ibnu 'Umar radbiallahu'anbuma yang hanya mengatakan bahwa kewajiban wanita hamil dan menyusui pada kondisi ini adalah fidyah, tanpa menyebutkan kewajiban mengqad $\vec{a}$. Karena hal tersebut sudah dipahami bahwa ketika seseorang berbuka saat ramadhan, maka wajib mengqad $\vec{a}$.

Pendapat ini adalah pendapat Syafi'iyyah $^{36}$ dan Hanabilah $^{37}$.

d. Keempat, mewajibkan wanita hamil untuk mengqadē'saja dan wanita menyusui untuk mengqad $\bar{a}$ ' disertai membayar fidyah.

Pendapat ini adalah pendapat Imam Malik rabimahullah. Beliau menqiyaskan wanita hamil layaknya seorang yang sakit, maka kewajibannya adalah mengqada à saja. Adapun wanita menyusui diqiyaskan kepada orang sakit dan orang tua yang tidak sanggup berpuasa, maka kewajibannya adalah membayar fidyah.

Adapun alasan yang lain kenapa juga diwajibkan qậd adalah karena wanita menyusui memungkinkan untuk menyewa ibu susuan untuk anaknya. Berbeda dengan wanita hamil, kekhawatiran kepada anaknya bagaikan kekhawatirannya pada salah satu anggota tubuhnya.

e. Kelima, tidak wajib bagi wanita hamil dan menyusui untuk mengqad $\bar{a}$ ' dan tidak pula membayar fidyah

${ }^{36}$ An-Nawawī, Al-Majmū' Syarh alMuhażżab, h. 177.

${ }^{37}$ Ibnu Qudamah al-Maqdisī, Al-Mugnī, h. 394.
Pendapat ini adalah madzhab Ibnu Hazm. Beliau berkata : Jika wanita hamil dan menyusui tidak berpuasa maka gugurlah kewajiban puasa baginya. Dan mewajibkan bagi wanita hamil dan menyusui mengqad $\vec{a}^{\prime}$ atau membayar fidyah tidak berdasar sama sekali baik kepada alQuran, asSunnah ataupun ijma'.

Pendapat terkuat adalah pendapat yang menyatakan cukup mengqad $\vec{a}$ ' saja. Ada dua alasan yang bisa diberikan:

Alasan pertama: Sebuah hadits dari Anas bin Malik al-Ka'bī ra bahwa Rasulullah saw bersabda:
نصنفَ الصيَّلَة

Artinya

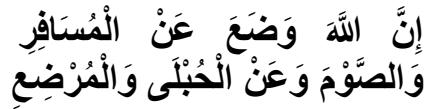

\section{"Sesungguhnya Allah} meringankan separuh shalat dari musafir, juga puasa dari wanita hamil dan menyusui." (38)

Al-Jașșāṣ ra menjelaskan, "Keringanan separuh shalat tentu saja khusus bagi musafir. Para ulama tidak ada yang berbeda pendapat mengenai wanita hamil dan menyusui bahwa mereka tidak dibolehkan mengqasar shalat. Keringanan puasa bagi wanita hamil dan menyusui sama halnya dengan keringanan puasa bagi musafir. Dan telah diketahui bahwa keringanan puasa bagi musafir yang tidak berpuasa adalah mengqad $\bar{a}$, tanpa adanya fidyah. Maka berlaku pula yang demikian pada wanita hamil dan menyusui. Dari sini juga menunjukkan bahwa tidak ada perbedaan antara wanita hamil dan menyusui jika keduanya khawatir membahayakan dirinya atau anaknya (ketika mereka

${ }^{38} \mathrm{HR}$. Abu Daud, At Tirmidzi, Ibnu Majah, An Nasa'i dan Al-Imam Ahmad]. Hadits ini dishohihkan oleh Asy Syaikh Al Albaani dalam Shahih Sunan Abu Daud no. 2409 
berpuasa), karena Nabi shallallabu 'alaibi wa sallam sendiri tidak merinci hal ini. ${ }^{39}$

Perkataan al-Jaṣṣāṣ ra ini sebagai sanggahan terhadap pendapat yang menyatakan wajib mengqad $\vec{a}$ ' bagi yang hamil sedangkan bagi wanita menyusui adalah dengan meng-qadäa dan fidyah, yakni memberi makan kepada orang miskin setiap hari yang ia tinggalkan.

Alasan kedua: Selain alasan di atas, ulama yang berpendapat cukup mengqad $\vec{a}$ saja (tanpa fidyah) menganggap bahwa wanita hamil dan menyusui seperti orang sakit. Sebagaimana orang sakit boleh tidak puasa, ia pun harus mengqad $\bar{a}^{\prime}$ di hari lain. Ini pula yang berlaku pada wanita hamil dan menyusui. Karena dianggap seperti orang sakit, maka mereka cukup meng-qad $\bar{a}$ ' sebagaimana disebutkan dalam firman Allah swt QS. al-Baqarah/2 184:

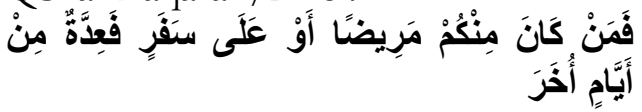

Terjemahnya:

Maka barangsiapa di antara kamu ada yang sakit atau dalam perjalanan (lalu ia berbuka), maka (wajiblah baginya berpuasa) sebanyak hari yang ditinggalkan itu pada hari-hari yang lain. ${ }^{40}$

Pendapat ini didukung pula oleh ulama zaman ini, seperti Syaikh 'Abdul 'Aziz bin 'Abdillah bin Baz $\mathrm{ra}^{41}$. Juga Syaikh Muhammad bin Shalih al-'Utsaimin ra, beliau mengatakan: "Saya lebih condong

${ }^{39} \mathrm{Al}$-Jașșāș, Ahkām al-Qurān, Juz I (Beirut, Dar Ihyā' al-Turāṡ al-'Arabī, 1992), h. 224.

${ }^{40}$ Kementrian Agama, Al-Qur'an dan Terjemahya, h.28.

${ }^{41}$ Abdullah Bin Baz, Fatwa nūrun 'alā addarb, Juz XVI (Cet.1, Riyadh, ar-Riāsah al-'Āmmah lil Buhūś al-'Ilmiyyah wal Iftā, 2010), h. 359-362. kepada pendapat bahwa wanita hamil dan menyusui hanya wajib mengqad $\vec{a}$, saja tanpa harus membayar fidyah, karena tidak adanya dalil yang kuat dan jelas untuk menopang wajibnya fidyah." ${ }^{(42)}$

Pertanyaan : Bagaimana dengan dalil wajibnya fidyah yang berasal dari riwayat Ibnu Abbas dan Ibnu 'Umar ra?

Pertama yang menjadi permasalahan adalah riwayat yang menyebutkan tentang fidyah adalah riwayat yang mauquf (perkataan sahabat). Apakah riwayat tersebut bisa dihukumi sebagaimana riwayat yang marfu' (yang riwayatnya sampai pada nabi) atau dia hanyalah sekedar perkataan sahabat dan hasil istinbat dan ijtihadnya saja?

Maka sebagian ulama kita berkesimpulan bahwa pendapat yang mewajibkan bagi wanita hamil dan menyusui membayar fidyah saja, merupakan pendapat yang marjüh dan lemah. Selain karena bertentangan dengan dalil-dalil yang jelas, juga riwayat-riwayat tersebut hanyalah hasil ijtihad sahabat dan tidak sampai pada tingkatan riwayat hadits yang marfu' yang bisa dijadikan dalil pegangan.

Hal ini juga dikuatkan oleh alJașșāṣ dalam bukunya ahkamul quran, beliau menyebutkan bahwa dalam masalah ini ada tiga pendapat dikalangan sahabat yakni : Ali berpendapat bahwa yang wajib bagi keduanya jika berbuka adalah qadha tanpa fidyah. Ibnu Abbas mengatakan bahwa yang wajib adalah fidyah tanpa qadha. Sedangkan ibnu Umar

${ }^{42}$ Faḥd al-Sulaiman, Majmū' Fatāwā wa rasāil Syaikh al-'Usaimīn, Juz XIX(Riyadh, Dar alsurayyā, 2003), h. 159-160. 
mengatakan bahwa yang wajib adalah qadha dan fidyah. ${ }^{(43)}$

Sebagaimana yang kita ketahui bahwa pendapat yang mewajibkan fidyah tanpa qadha berdalilkan riwayat manquf (perkataan sahabat) yakni ia adalah hasil ijtihad masing-masing, sehingga mereka pun berbeda dalam penerapan hukum. Sebuah kaidah usul mengatakan bahwa jika perkataan sahabat diselisihi sahabat yang lain, maka perkataan sahabat tersebut tidak bisa dijadikan hujjah atau dalil pegangan tanpa ada dalil yang lain yang menguatkannya.

Maka dari itu sebagian ulama berkesimpulan bahwa kewajiban fidyah yang berasal dari riwayat tersebut dibawa kepada keadaan yang dimana wanita hamil dan menyusui tidak mampu berpuasa sama sekali. Maka kondisi seperti ini diqiyaskan kepada orang tua renta dan orang sakit yang tidak ada harapan baginya untuk sembuh. ${ }^{(44)}$

\section{Kesimpulan Masalah:}

Setelah meninjau kembali masalah ini, kami pun tetap pada kesimpulan pertama, walaupun dengan tambahan penjelasan kondisi wanita hamil dan menyusui yang telah kami sebutkan. Secara singkat kesimpulan tersebut sebagai berikut:

1. Wanita hamil dan menyusui yang mendapatkan rukhsah tidak berpuasa, baik karena khawatir pada dirinya atau anaknya atau keduanya, maka ia hanya wajib menqad̄a puasa yang ditinggalkan.

2. Wanita hamil dan menyusui tetap diharuskan menqadà puasa yang ditinggalkan jika ia masih mampu untuk berpuasa di lain waktu.

${ }^{43} \mathrm{Al}$-Jașșāṣ, Ahkām al-Qurān, h. 224.

${ }^{44}$ Faḥd al-Sulaiman, Majmū' Fatāwā wa rasāil Syaikh al-'Uśaimīn, h. 165-166.
Karena keadaanya diqiyaskan seperti orang sakit, juga seperti musafir sebagaimana pada penjelasan hadits Anas bin Malik al-Ka'bi.

3. Adapun beralih pada fidyah tanpa qadā, jika kondisi wanita hamil dan menyusui tidak mampu berpuasa sama sekali dan tidak mampu mengqada puasa yang ia tinggalkan. Maka kondisi seperti ini diqiyaskan pada orang tua renta dan orang sakit yang tidak ada harapan sembuh baginya.

4. Adapun kondisi hamil dan menyusui dialami wanita yang berlanjut terus menerus selama bertahun-tahun, maka kembali pada tiga poin sebelumnya. Selama masih bisa untuk mengqada puasa maka ia wajib berpuasa tanpa beralih kepada fidyah, kapan pun ia memiliki waktu untuk mengqad à.

- Adapun kondisi ini sebagaimana yang disebutkan, sepertinya tidak mungkin seorang wanita hamil dan menyusui terus menerus selama bertahun-tahun sehingga tidak memiliki waktu untuk mengqada. Mengingat bulan ramadhan yang berkisar antara 29 atau 30 hari, dan setelahnya ada 11 bulan yang memungkinkan baginya untuk membayar utang puasa yang ditinggalkan.

- Oleh karena itu kami nasehatkan kepada para muslimah untuk bertakwa kepada Allah dalam permasalahan ini. Karena sebagian kaum muslimin mengambil fatwa sebagian ulama yang mencukupkan mengganti puasa bagi wanita hamil dan menyusui dengan membayar fidyah saja dalam kondisi apapun 
dengan anggapan bahwa syariat ini mudah. Dan konsekuensi yang paling mudah dan ringan adalah fidyah. Padahal fidyah adalah konsekuensi hukum yang dijalankan ketika sudah benarbenar tidak mampu untuk mengqa ${ }^{a} \bar{a}$ puasa, seperti orang tua renta yang tidak sanggup sama sekali berpuasa dan orang sakit yang tidak diharapkan kesembuhannya. Sedangkan wanita hamil dan menyusui adakalanya masih sanggup berpuasa, ada juga yang tidak memungkinkan baginya berpuasa pada kondisi tertentu, namun masih sanggup untuk menggantinya (puasa qadà) di hari yang lain. Wallahu 'alam.

Faktor dan penyebab utama menumpuknya utang puasa bagi wanita yang bertahun-tahun dalam kondisi entah hamil atau menyusui, adalah kelalaian. Maka wanita yang memiliki keadaan dan kondisi seperti ini harus memperhatikan waktu-waktu yang dimana kondisinya memungkinkan ia untuk membayar utang puasanya. Salah satu caranya adalah dengan berkonsultasi dengan ahli/dokter.

\section{KESIMPULAN}

1. Rukhșah adalah hukum yang berlaku berdasarkan suatu dalil, yang menyalahi dalil hukum yang sudah ada(hukum asal/'azimab) karena adanya udzur.

2. Udzur yang dianggap sebagai sebab rukhșah diantaranya: safar, sakit, paksaan, lupa, kebodohan, keadaan yang sangat sulit dihindari, dan kekurangan.

3. Secara singkat udzur atau sebab seseorang mengambil rukhșah itu bisa berupa adanya keterpaksaan (ad-darūrah), atau adanya kesulitan (al-masyaqqah) ataupun sekedar kebutuhan (al-häjab).

4. Rukhșah adalah keringanan. Dan bentuk keringanan dalam ibadah puasa adalah, keringanan untuk tidak berpuasa pada bulan ramadhan dengan konsekuensi mengganti puasa yang ditinggalkan sesuai dengan ketentuan yang telah digariskan oleh syari'at. Yakni dengan qad ä' atau fidyah.

5. Golongan yang Mendapatkan Rukhșah dalam Ibadah Puasa.

a. Orang sakit yang jika berpuasa akan bertambah parah sakitnya, atau bisa berakibat kematian. Maka ia wajib berbuka dan wajib mengqad $\bar{a}$. Adapun sakit yang ringan maka bukan merupakan udzur.

b. Musafir yang mendapatkan keringanan untuk mengqașar shalat, mengambil rukbșah tidak berpuasa, dan wajib mengqad ä.

c. Wanita haidh dan nifas wajib berbuka dan wajib mengqad $\vec{a}$.

d. Orang tua renta dalam keadaan lemah, dan orang sakit yang tidak diharapkan kesembuhannya, mengambil rukhșah tidak berpuasa, tidak wajib mengqad $\bar{a}$, tapi wajib membayar fidyah.

e. wanita hamil atau menyusui bukan merupakan udzur atau sebab wanita mendapatkan rukhșah untuk tidak berpuasa. Jika kuat melaksanakan puasa dan tidak sulit baginya tanpa adanya mudharat, maka wajib puasa. Sebaliknya, ia wajib berbuka jika mengkhawatirkan dirinya atau dirinya dan 
anaknya, maka ia wajib mengqad $\vec{a}$. Tapi jika ia hanya mengkhawatirkan anaknya saja, para ulama berbeda pendapat dan yang rajihnya adalah cukup mengqad $\vec{a}$.

\section{DAFTAR PUSTAKA}

Kementrian Agama, Al-Qur'an dan Terjemabya. Depok; Sabiq 2012.

Al-Albani, Muhammad Nashiruddin. Irwà' al-Galil, Juz IV. Cet.1, Beirut; al-Maktab al-Islami, 1979.

Bin Baz,Abdullah. Fatwa Nürun 'alā Al-Darb, Juz.XVI. Cet.1, Riyadh; ar-Riāsah al-'Āmmah lil Buhūis al-'Ilmiyyah wal Iftā, 2010.

Al-Bukharī, Muḥammad ibn Ismāīl ibn Ibrāhīm ibn Al-Mugīrah. Șaḥịh Al-Bukharì, Juz IX. t.p; Dār Ṭauq Al-Najāh, $1422 \mathrm{H}$.

Al-Duwaysy, Ahmad. Fatāwā al-Lajnah ad-Däimah, Juz.X. cet 1, Riyāḍ; Dar al-'Āṣimah, 1996.

Ibn Hanbal, Aḥmad. Musnad Al-Imām Ahmad Ibn Hanbal Juz X. cet, II; t.p, Muassasah Al-Risālah, 1999.

Ibn Khuzaimah, Muhammad Ibn Ishāq. Saḥīh Ibn Khuгaimah, Juz III. Bairūt; Al-Maktab AlIslamiyah, 1970.

Al-Jașșāṣ, Aḥkām al-Qurān, Juz I. Beirut, Dar Ihyā' al-Turās al'Arabī, 1992.

Kementrian Agama Kuwait, alMawsū'ah al-Fiqhiyyah Juz XXII. Cet.1, Kuwait, Dār as-ŚSafwah, 1995.

Al-Manẓūr, Ibnu. Lisan al-'Arab, Juz VII. Cet.3, Beirut, Dār Sādir, 1994.

Al-Maqdisī, Ibnu Qudamah. Al-Mugni, Juz IV. Cet.III, Riyadh; Dār 'Ālam al-Kutub, 1997.
Al-Naisāburī, Muslim Ibn Al-Hajjāj Al- Qusyairī. Șahịh Muslim, Juz II. Bairūt; Dār Al-Kutub AlArābiyah, 2010.

Al-Namlah, Abdul Karim. Al-Rukhas Al-Syar'iyyah wa Iśbātubà bi AlQiyàs. Cet.1, Riyadh, Maktabah ar-Rusyd, 1990.

Al-Nawawī, Al-Majmū' Syarh alMuhażżab Juz VI. Cet.1, Beirut; Dar al-Turasं al-'Arabī, 2001.

Sayyid Salim, Kamal bin. Șahịh Fiq̣h Sunnah, Juz II. cet.1, Cairo; alMaktabah al-Tawfíqiyyah.

Al-Sulaiman, Faḥd. Majmü' Fatāwā wa rasāil Syaikh al-'Uśaimin, Juz XIX. Riyadh; Dar al-Surayyā, 2003.

Al-Suyūṭī, Al-Asybāh wa Al-Nazaīir. Cet.1, Beirut; Dar al-Kutub al'Ilmiyah, 1983. 